\title{
СВАКОДНЕВНИ ЖИВОТ СРБА У ТЕМИШВАРУ ПРЕ И НАКОН ЗАВРШЕТКА ПРВОГ СВЕТСКОГ РАТА
}

\begin{abstract}
Током рада на докторској дисертацији Темишварски Срби и прва југословенска држава 1918-1921. године сакупила сам велики број података о свакодневном животу Срба у Темишвару у периоду провизоријума између српске и румунске власти након завршетка Првог светског рата. Крај Првог светског рата Срби у Банату дочекали су схватања да Аустро-угарска монархија није њихова права домовина, а њихов отпор према рату показао је жељу за променом режима и чежњу за националним уједињењем са браћом изван црно-жуте монархије. Темишвар у то време бива центар српског Баната, али није српска варош. У граду од преко седамдесет и четири хиљаде становника живело је само око четири и по хиљаде Срба. Остало становништво било је немачко, мађарско, румунско и јеврејско. О таквом Темишвару сазнајемо из писања Милоша Црњанског, који је у њему живео у годинама пред Велики рат. Сећања Црњанског доносе нам значајне податке о свакодневном животу, навикама али и о проблемима темишварских Срба пре почетка рата. Након завршетка Првог светског рата присутво српске војске српско становништво у Темишвару доводи у положај грађана првог реда и за њих, без сумње, отпочиње другачији свакодневни живот од онога који су водили као народности са ограниченим правима у бившој Аустро-угарској. Праћење српске банатске штампе, у највећој мери листа Слога, који је излазио у Темишвару од децембра 1918. године до краја јула 1919. године, а чија се периодика чува у Библиотеци Матице српске у Новом Саду доноси нам велики број података о њиховом свакодневном животу.
\end{abstract}

Кључне речи: Темишвар, Срби у Темишвару, српски империјум, свакодневни живот, 1918. година, 1919. година.

Бављење друштвеном историјом, поред политичке, представљало је велики научни задатак. Иако је у свету одавно постало уобичајено да се проучава појединац, обичан човек, код нас се историчари у већој мери баве историјским личностима, политичарима, онима за које се сматра да су променили ток историје. У докторској дисертацији, у поглављима о свакодневном и културном животу темишварских Срба на основу историјских извора покушала сам да то променим. Свакодневницом темишварских Срба бавила

\footnotetext{
${ }^{1}$ majovanakasas@yahoo.com
} 
сам се и у научном раду објављеном у гласнику Историјског архива у Кикинди Attendite, али користећи један другачији приступ. Односно, научни циљ био је да се покаже како се свакодневни живот становника српске националности променио услед промене административне власти. [в. Касаш, 2018б: 91-102]. У овом научном раду износим нове податке о свакодневном животу Срба у Темишвару до којих сам дошла из различитих извора на српском језику. У највећој мери коришћена је дневна штампа, али и сећања савременика и радови других истраживача.

За разлику од неких ранијих научних радова, сматрам, да је, најпре, важно утврдити демографске податке. Под термином - Срби у Темишвару узела сам Србе који су живели у Темишвар-Граду и у његова два предграђа Мехали и Фабрици. У Банатском алманаху, првој публикацији која је на српском језику изашла у Темишвару, објављено је да је по попису становништва из 1822. године Епархија темишварска имала сто седамдесет хиљада четири стотине и тридесет и два становника српске народности. [Граховац, 2010: 352]. Међутим, по попису из 1910. године у самом граду Темишвару од преко седамдесет и четири хиљаде становника живело је само око три и по хиљаде (3490) Срба [Нојман, 2013: 391-412]. Стеван Бугарски [2004: 766] користећи податке које је прикупио Љубомир Степанов сматра да је Срба 1910. године било још мање - и то две хиљаде четристо осамдесет и два. По пребројавању које су вршиле српске црквене општине уочи одржавања Велике народне скупштине у Новом Саду, а која вероватно нису реална слика, Срба је у Темишвару било више од четири и по хиљаде. [РОМС, Пуномоћи посланика, М. 7. 417]

О таквом Темишвару сазнајемо из писања Милоша Црњанског, који је у њему живео у годинама пред Велики рат - до 1912. године [в. Црњански, 1989]. Сећања Црњанског доносе нам значајне податке о свакодневном животу, навикама, али и о проблемима темишварских Срба. Како пише Црњански [1989: 31] Темишвар је тих година био модерна, раскошна и огромна варош са широким авенијама и парковима, окружена бедемима старе, жуте тврђаве. У чланку који је објавио лист Политика 1925. године Црњански је писао да је Темишвар био подељен дугим алејама, које су зими биле завејане, а којима се ноћу враћало из позоришта „дуж огњишта у крпе завијених баба, које су пржиле кестење и говориле нарочити швапски дијалект“ [в. Милош Црњански, Наш Темишвар, Политика, бр. 6001, 6, 7, 8. јануар 1925, стр. 16]. „Свет се ту шетао, као што се у Италији шета“, а називали су га и „Малим Бечом“ [Црњански, 1989: 31]. У Темишвар-Граду, у порти српске Саборне цркве, прекопута католичке катедрале, налазила се мала школа српског учитеља, Душана Берића, код кога је Црњански учио четири разреда основне школе. Да је био уложен велики труд да српска деца од малена буду упозната са народним и црквеним правима Срба у Аустро-угарској видимо баш на основу сведочења Црњанског, који за свог учитеља Берића каже да је 
био експерт за ова питања и да је њих, ученике, свако вече окупљао код себе да им о томе прича. У свом делу О Банату и о Банаћанима, Милош Црњански [1989: 31-34] пише и како је Темишвар нагло растао и развијао се, да се налазио на води и имао веслачке клубове, а да су се Темишварке облачиле по последњој моди из Париза, која је долазила преко Беча.

Млади писац је до матуре живео са мајком, као што су у то време живела сва „варошка деца“. Дружио се са децом католика, племића и како каже, са њиховим намирисаним сестрама са којима је похађао часове француског. Упоредо је похађао и часове енглеског језика и сликарства, али истиче да то није био израз никаквог снобизма, него једна уобичајена појава у Темишвару у то време. Црњански пише да је „усред града, око петокатних кућа, луксуз био неизмеран, мирис пудера и парфема увек јак“, али да су се на мостовима преко Бегеја, дешавала ноћу права великоварошка убиства [Црњански, 1925: 16]. Црњански је живео и међу радницима. У клубу железничара, металаца, играо је фудбал, где му је најбољи друг био металац Сидон па је тако у његовом друштву, како сам пише, упознао језик, кућу, породични живот радника и литературу социјализма [Црњански, 1989: 35-36].

За нашу тему најзначајнији пасуси из сећања Милоша Црњанског су они у којима пише о „Темишвару Срба“. Његова сведочења су важна да би се схватио положај темишварских Срба уочи избијања Великог рата и да би се разумело зашто су они природно нагињали да се присаједиње првој југословенској држави, иако многи од њих Србију никада нису ни видели и нису били потпуно национално свесни [Касаш, 2018a: 40]. Црњански је писао да је једно руско певачко друштво дошло са севера и „узбунило све својим тужним, славенским литургијама“, а да су глумци причали о Србији свој завејаној цвећем шљива. Њихове улоге научиле су темишварске Србе да, како је писао Црњански, осим „нашег кукања на гробљу и осим наше мале школе, у којој су нам једнако причали о спаљивању моштију, о набијању на колац, има још један свет у коме се игра и грли“ [Црњански, 1925: 16]. Такође, Црњански је писао да је поред Темишвара мађарских племића и Темишвара пролетера и металаца, постајао и један други Темишвар којем је породица Црњански тада припадала „и душом и телом“. То је био „Темишвар Срба““. „Варош стара, умирућа, фанатична, верска. Дијаспора, као и Темишвар Јевреја“, писао је Црњански. За такав Темишвар, Црњански каже да је са Темишварем туђина „срастао“ као два сијамска близанца али окренута леђима. „У том Темишвару бранила се свака српска кућа, као барикада““ [Црњански, 1989: 37].

Као што смо напоменули, Срби су живели у Темишвар-Граду, Мехали и Фабрици. Од самог града до новог утврђења размак је морао да буде онолико колико прелети једно топовско ђуле. Стеван Бугарски и Љубомир Степанов пишу да је због тог великог размака и мало путева свако предграђе живело својим животом [Бугарски, Степанов, 2008: 10]. Милош Црњански је писао да је Срба 
у Темишвар-Граду уочи почетка Првог светског рата „већ било мало“, али да се на пола сата хода, иза огромног купатила и петоспратних хотела, где су отмене жене ишле на састанке - у Мехали, могло „под расцветаном јабуком, на дрвеној клупи, уз пламен једне свеће, пити кисело вино и певати, уз тамбуру, о болном Кара-Мустафи“. Иза Темишвар-Града налазила се зелена, лепа архијерејска башта, гробље и пут, засађен багремом, који је водио у Мехалу. У Мехали је, како пише Црњански, становала „српска резерва, све сами радикали, сви бербери и све калфе, који су у белим рукавицама играли, по баловима женске задруге“. У Мехали је „под мирисом фризура“ ипак српство било очувано [Црњански, 1925: 16]. С. Бугарски и Љ. Степанов [2008: 32.] пишу да су пред крај 19. века Мехалчани мањим делом били земљорадници и надничари, а већим делом сувачари, дунђери, зидари, ћурчије, кириџије, чизмари, трговци, кројачи, фабрички радници, чиновници и слично. Мехала је 1. јануара 1910. прикључена Темишвару као његово предграђе под називом са називом Ференцварош, немачки Францштат, док су је Срби посрбљавали у Фрањоград.

За предграђе Фабрика, М. Црњански [1925: 16] је писао да је било „црно и чађаво“ и да је имало своју читаоницу и књижевне вечери. „Гласно су се читали Ветар и Дона Клара и увек је било пуно. Тај свет, који је почео да муца свој језик, долазио је ту са лудим одушевљењем. Сваки ко је умро, остављао је своје имање цркви и на књиге“, писао је Црњански [1925: 16] за Србе који су живели у предграђу Фабрика.

Када обрађује период четрдесетих година 19. века у Темишвару, Д. Попов [2015: 90] каже да је у Темишвар-Граду, и када гледамо купо-продају и када гледамо изнајмљивање некретнина, у односу на остала предграђа, стамбена вредност била највећа. Др Ђорђе Лазаревић [2013: 72-73] из Новог Сада је такође, за шездесете године 19. века и за период неколико година пре Првог светског рата писао да је у предграђу Фабрика било јефтиније становати него Темишвар-Граду. „И животне намирнице биле су у Фабрици много јефтиније, него у граду“, писао је Лазаревић [2013: 72-73].

Ђ. Лазаревић се сећао како се први пут возио железницом када је као дете долазио у Темишвар на школовање [Лазревић, 2013: 50]. Како је писао М. Црњански $[1925,16]$ у Темишвару се налазила огромна железничка станица, која је била већа од београдске и која се „црвенила као запаљено предграђе, и засипала све паркове гаром и димом“. На саобраћај у Темишвару, посебно на возаче фијакера жалио се лист Слога. Наиме, становништво Темишвара жалило се да су фијакеристи „немилосрдни“ и „да би путницима и кожу с леђа здерали“. Одбијали су да возе у одређене четврти, ноћу су наплаћивали изузетно велике цене, па би тако путнику од железничке станице до темишварског предграђа Мехале наплаћивали педесет круна [Слога, бр. 129, Темишвар, 19. мај 1919, стр. 2].

У Темишвару је у време уласка српске војске од преко седамдесет четири хиљаде становника живело четири и по хиљаде Срба и око седам и по 
хиљада Румуна. Остало становништво било је немачко, мађарско и јеврејско. [Церовић, 1997: 413] По именима и презименима власника радњи и гостионица у Темишвару закључујемо да су њих у прво време након Првог светског рата држали управо Немци, Јевреји и Мађари. Тако је на страницама листа Слога оглас за своју радњу дао Ђула Галгон и то за радњу са деликатесима у улици Јене Херцег на броју 5 [Слога, бр. 10, Темишвар, 21. (8.) децембар 1918, стр. 2]. У овој трговачкој радњи мешовите робе 1911. године ступио је као шегрт Србин Франц Бранислав Мирчетић, где је поред обављања редовних дужности почео да се вежба у аранжирању излога. Франц Бранислав Мирчетић рођени је Темишварац, крштен је у српској православној цркви, а кретајући се у круговима других националности потписивао се као Франциск [Марков, Демиан, 2017: 107-125]. Иако је једва говорио српски језик, изјашњавао се као Србин, учествујући активно у животу српске заједнице у међуратном Темишвару. По професији је био трговац, али је интересантно да се највише прославио као дипломирани декоратер излога. Године 1912. отишао је у Берлин где је похађао академско-трговачки курс за младиће који су желели да овладају вештином укршавања излога. На том течају било је две стотине учесника. Дана 30. новембра 1924. године у Темишвару је држао два вечерња течаја. Течај је трајао четири месеца, а било је уписано је деведесет слушалаца. Најављен је као „наш Србин“, трговачки помоћник деликатесне радње Бабчањи, „о чијој спреми и вештини беше већ речи у нашем листу“ [Гласник, бр. 2, Timişoara (Темишвар), 15. јануар 1925, стр, 15].

Гостионичари и власници радњи у Темишвару покушавали су да приволе српско становништво и српске официре и војнике док су били стационирани у граду. Јосиф Лунцер је у кафани „Централ“ војницима давао попуст од двадесет посто, док је Франац Алберт молио за што већу „српску посету“ у својој кафани „Полгари“ у Јозефвароши, као и хотелијер кафане „Хоргон“ у истој вароши [Слога, бр. 1, Темишвар, 11. децембар (28. новембар) 1918, стр. 2; Слога, бр. 19, Темишвар, 3. јануар 1919. (21. децембар 1918), стр. 4]. Оскар Сенеш је своју радњу у Мерци улици рекламирао уз назнаку да се у њој стално налазио велики избор српских грамофонских плоча [Слога, бр. 19, Темишвар, 3. јануар 1919. (21. децембар 1918.), стр. 4]. У златари Симона Гондмана у Темишвару у Мерци улици истицало се да се говори и српским језиком, као и у радњи са алкохолним пићима Јакаба Пфенда [Слога, бр. 18, Темишвар, 1. јануар 1919. (19. децембар 1918.), стр. 4]. Јефта Франк и Виктор Лидолт су на исти начин рекламирали своју продавницу коже, односно своју радњу за женску тоалету [Слога, бр. 19, Темишвар, 3. јануар 1919. (21. децембар 1918.), стр. 4; Слога, бр. 44, Темишвар, 4. фебруар 1919, стр. 4]. Да се у салону говорио српским језиком и да су се официри, подофицири и чиновници молили за посету, писало је и у реклами за берберски салон Марије Њагул у Хуњади улици на броју 2, а у 
књижари „Полачек“ у Белвароши истицано је да су у свом асортиману имали велики избор српских књига [Слога, бр. 10, Темишвар, 21. (8.) децембар 1918, стр. 2; Слога, бр. 62, Темишвар, 25. фебруар 1919, стр. 4]. У радњи са деликатесима „Жужи“ која се налазила у близини хотела „Лојд“ као шегрт након завршекта Првог светског рата радио је, већ помињани, Франц Бранислав Мирчетић [Слога, бр. 42, Темишвар, 1. фебруар 1919, стр. 4].

У листу Слога било је реклама и за радње чији власници имају српско име и презиме, мада ретко. Број таквих реклама се повећавао како је одмицао „српски империјум“ у Темишвару који је трајао до јула 1919. године. И у Меморандуму темишварске Eпархије стајало је да од како се српска војска налазила у граду да су се множили Срби трговци и занатлије [Архив Југославије, Делегација, Ф. 3, 19. августа 1919. године]. Тако видимо да је у Темишвар-Граду Милан Јорговић, сарач-седлар, у Принц Евегеније улици на броју 11 отворио своју занатску радњу, а Жика Перић берберски салон у Варошкој улици на броју 12 [Слога, бр. 13, Темишвар, 25. (12.) децембар 1918, стр. 3; Слога, бр. 19, Темишвар, 3. јануар 1919. (21. децембар 1918.), стр. 4]. Светозар Мартинов, фризер, у једном од бројева темишварске Слоге свим Србима православне вере честитао је Нову годину, а Милан Лазаревић рекламирао је своју трговину косе у темишварској четврти Јозефварош у Хуњади улици на броју 15 [Слога, бр. 42, Темишвар, 1. фебруар 1919, стр. 4]. Српски фризерски салон Душана Бугарина у Темишвар-Граду налазио се преко пута Војне болнице, а ресторан „Касанић“ код старог Шпилура [Слога, бр. 43, Темишвар, 2. фебруар 1919, стр. 4; Слога, бр. 27, Темишвар, 15. (2.) јануар 1919, стр. 4]. Рибарница „Код Радића“ налазила се у предграђу Фабрика у Нађ Телтеш улици на броју 25 [Слога, бр. 44, Темишвар, 4. фебруар 1919, стр. 4]. Коста Антоновић држао је посластичарску радњу у Фабрици у Главној улици [Слога, бр. 45, Темишвар, 5. фебруар 1919, стр. 4]. Дуванџиница, трафика А. Арсеновића, налазила се у Темишвар-Граду „вис а вис“ „Кронпринца“, ресторан код чика Илије такође у Темишвар-Граду, а кројачка радња Јулке Стојановић у Принц Евгеније улици на броју 11 [Слога, бр. 46, Темишвар, 6. фебруар 1919, стр. 4; Слога, бр. 53, Темишвар, 14. фебруар 1919, стр. 4; Слога, бр. 60, Темишвар, 22. фебруар 1919, стр. 4]. Србин Филип Губић држао је гостионицу „Три руже“ у Темишвару [Слога, бр. 81, Темишвар, 19. март 1919, стр. 4]. Велимир Петковић, воскар, имао је радњу у Фабрици, а Михајло Вујовић држао је официрску „Касину“ [Слога, бр. 125, Темишвар, 15. мај 1919, стр. 2]. Средином јуна 1919. године лист Слога донео је вест да се Србин из Ужица, Срета Неагић, преселио из Официрске касине у Хотел „Мали Бристол“ на Лошонци тргу и тамо отворио своју ћевабџиницу [Слога, бр. 147, Темишвар, 11. јун 1919, стр. 2].

У листу Слога под насловом Поштена налазачица донет је чланак који је описао једну ситуацију из свакодневнице темишварских Срба у којем пише да је Софија Гавриловић, „кћи нашег честитог господина Милана 
Гавриловића, благајника Српске Штедионице у Ференц-вароши (Мехали) нашла 7.165.50 круна пред Српском Штедионицом“ и да је исти новац полиција потом вратила Сими Марашу из Мехале [Слога, бр. 22, (Темишвар), 7. јануар 1919. (25. децембар 1918.), стр. 2]. Овај чланак навео ме је да из достуних извора истражим више о „Темишварској Српској Штедионици“ са којом су Срби у Темишвару свакодневно долазили у додир пре и након Великог рата. Сврха овог друштва по статутима које је друштво донело 18. фебруара 1911. године била је да „прима улоге на приплод и да тиме унапређује штедњу и образовање капитала, па да обезбеђеним смештењем капитала а поред користоноснога улагања своје деоничке главнице унапређује интересе пољске привреде, обрта и трговине и потпомаже у опће материјално благостање“ [Штатути „Темишварске Српске Штедиониие“ деоничарског друштва, Велика Кикинда, 1911, 3]. Фирма друштва на српском језику гласила је „Темишварска Српска Штедионица, Деоничарско Друштво“, на мађарском језику: „Temesvári Szerb Takarékpénztár, Részvénytársaság“, а на немачком језику „Temesvárer Serbische Sparkassa, Aktien-Gesellschaft“. Обjaве друштва обнародоване су једном годишње у званичном листу Budapesti Közlöny, а управни одбор друштва имао је права да објављује вести и у другим новинама и по више пута годишње. Званични језик друштва био је српски језик, са ћирилицом као званичним писмом. Друштвени органи били су скупштина, управни одбор и надзорни одбор. Скупштина друштва бирала је почасног председника са доживотним мандатом [Штатути „Темишварске Српске Штедионище“ деоничарског друштва, 16]. Почасни председник био је Лазар Дунђерски, велепоседник из Сентомаша (данас Србобран). Прва пословна година била је 1912. година [БМС, сигнатура П ІІІ 17351/1912]. Дана 25. јануара 1913. године упућен је позив на редовну главну скупштину 1. марта 1913. године која се одржала у дворани српског православног епископског двора у Темишвару. Председник управног одбора био је Иван Мучалов велепоседник, потпредседник Шандор Ненадовић трговац и поседник, а чланови управног одбора од Срба из Темишвара били су Јован Новаковић окружни протопрезвитер и поседници Ранко Славнић и Андрија Гавриловић. У надзорном одбору од темишварских Срба био је Светолик Живковић трговац као председник одбора и Михајло Живановић варошки капетан као члан. Иван Берић био је књиговођа друштва [БМС, сигнатура П III 17351/1912].

Седма редовна главна скупштина „Темишварске Српске Штедионице“ одржана је 31. марта 1919. пре подне у дворани српског православног епископског двора у Темишвару. Иван Берић је наведен као пословни директор, Анђелко Станојев као књиговођа, а управни одбор чинили су Иван Мучалов као председник, Александар Ненадовић потпредседник, а Јован Новаковић, Гера Живановић, др Гедеон Дунђерски, Андрија Гавриловић, Марко Богдан, Ранко Славнић, Стеван Карамата, Миливој Стевановић чланови. Председ- 
ник надзорног одбора био је Светолик Живковић, а Миливој Шићаревић, Христифор Свирчевић, Милош Станковић и др Михајло Живановић чланови [Слога, бр. 75, Темишвар, 11. март 1919, стр. 4].

Када се Темишвар након разграничења нашао у Краљевини Румунији, 17. априла 1920. године у просторијама штедионице одржала се редовна осма главна скупштина „Темишварске Српске Штедионице“. Са 31. децембром 1919. године завршена је осма пословна година и у прошлогодишњем извештају истакнуто је да се за годину 1919. „већ унапред указују послови те да ће Штедионица свој посао проширити трговином робе“. То је и учињено те је са задовољством констатовано да је над овим пословима постигнут леп успех. Поводом наступеле промене у земљи направљене су одређене измене. Поред поменуте фирме друштва на српском језику, мађарском и немачком додата је и фирма на румунском језику која је гласила „Casa de Păstrare Sarbeăscă din Timişoara, Societate pe Acţiuni“ Печат друштва који је раније изгледао тако да је у средини изрезана година 1911. и око тога је стајао натпис „Темишварска Српска Штедионица“, - „,Temesvári Szerb Takarékpénztár.“ ce променио тако што је у средини изрезана година 1911. и око тога је стајао натпис „Темишварска Српска Штедионица“ - „Casa de Păstrare Sarbeăscă din Timişoara“. Објаве друштва нису се више објављивале у листу Budapesti Közlöny него у једном темишварском градском листу. Управни одбор су од марта 1920. године чинили почасни председник др Гедеон Дунђерски и од темишварских Срба Иван Мучалов као председник, Шандор Ненадовић трговац и поседник као потпредседник, а Јован Новаковић окружни протопрезвитер, др Миливој Стефановић градски лекар, Светолик Живковић трговац, Андрија Гавриловић трговац и поседник као чланови. Председник надзорног одбора био је др Михајло Живановић, а Христифор Свирчевић (сада школски референт из Новог Сада) и Живојин Миладинов, трговац и поседник из Темишвара чланови [БМС, сигнатура П ІІІ 17351/1919].

Оновремена дневна штампа и сећања савременика садрже обиље података о свакодневном животу темишварских Срба и они су увек слика једног времена. Међутим, свесна сам и да треба бити обазрив и критички радити на оваквој врсти извора.

\section{Литература}

Бугарски, Степанов, 2008: С. Бугарски, Љ. Степанов, Срби у Темишвару-Mехала. Темишвар: Савез Срба у Румунији.

Бугарски, 2004: С. Бугарски, Срби у Темишвару, Ниш: Теме, часопис за друштвену теорију и праксу, бр. 2, Универзитет у Нишу, 765-778.

Граховац, 2010: С. Граховац, Српска књижевност у Банату, у: Банат кроз векове, слојеви култура Баната. Београд: Вукова задужбина, 349-378. 
Касаш, 2018а: Ј. Касаш, Самоопредељење темишварских Срба да се присаједине Краљевству Срба, Хрвата и Словенаца, Београд: Култура: часопис за теорију и социологију културе и културну политику, бр. 159, Завод за проучавање културног развитка, 37-50.

Касаш, 2018б: J. Касаш, Срби у Темишвару као грађани првог реда: свакодневни живот, Кикинда: Attendite: Гласник Историјског архива у Кикинди, бр. 15, Архив Кикинда, 91-102.

Лазаревић, 2013: Ђ. Лазаревић, Моја биографија (Приредили: Гордана Ђилас и Драго Његован). Нови Сад: Градска библиотека.

Нојман, 2013: V. Neumann, Timişoara between "Fictive Ethnicity" and "Ideal Nation" The Identity Profile during the Interwar Period, Beograd: Balcanica XLIV, 391-412.

Марков, Демиан: 2017: 3. Марков, Н. Демиан, Србин особењак у међуратном Темишвару: Франц Бранислав Мирчетић (1897-1983), Нови Сад: Темишварски зборник, бр. 9, Матица српска, 107-125.

Попов, 2015: Д. Попов, О Темишвару и темишварским Србима из времена Бранковог школовања (1841-1843), у: Радичевићи у Темишвару. Темишвар: Савез Срба у Румунији, 89-102.

Церовић, 1997: Љ. Церовић, Срби у Румунији. Нови Сад: Матица српска.

Црњански, 1989: М. Црњански, О Банату и о Банаћанима (Приредио: Стојан Трећаков). Нови Сад: Књижевна заједница Новог Сада.

Штатути „Темишварске Српске Штедионице“ деоничарског друштва, Велика Кикинда 1911.

\section{Извори}

Архив Југославије, Београд (АЈ)

Библиотека Матице српске (БМС)

Рукописно одељење Матице српске, Нови Сад (РОМС)

\section{Штампа}

Политика, Београд (1925)

Гласник, Timişoara (1925)

Слога, Темишвар, Велики Бечкерек $(1918,1919)$ 
Jovana Kasaš

\section{EVERYDAY LIFE OF SERBS IN TIMISOARA BEFORE AND AFTER THE END OF WORLD WAR I}

\section{Summary}

During the work on the doctoral dissertation entitled Serbs in Timisoara and the First Yugoslav State 1918-1921, I collected a vast amount of data about the everyday life of Serbs in Timisoara in the interim period between Serbian and Romanian rule in the aftermath of World War I. The end of World War I saw Serbs in Banat believing that Austro-Hungarian monarchy is not their true homeland, and their resistance to war indicated a wish for change of regime and longing for unification with their brethren outside of the black and yellow monarchy. Timisoara was the center of Serbian Banat at the time, but it was not a Serbian town. In the town of over seventy-four thousand inhabitants, there were only around four and a half thousand Serbs. The remaining population was German, Hungarian, Romanian and Jewish. We traced Timisoara of the time from the writings of Miloš Crnjanski, who had lived in it for years preceding the Great War. Memories of Crnjanski bring us valuable facts about the everyday life, habits and also problems of Serbs in Timisoara before the outbreak of World War I. After the end of the war the presence of Serbian army makes Serbian population in Timisoara first rate citizens and for them undoubtedly begins a different everyday life than the one they led as minority with limited rights in the former Austro-Hungaria. Tracing Serbian press in Banat, and mostly the paper Слога, which came out in Timisoara from December 1918 till July 1919, and whose incomplete archives are kept in the Library of Matica srpska in Novi Sad, bring us a great number of data concerning their everyday life.

Key words: Timisoara, Serbs in Timisoara, Serbian imperium, everyday life, 1918, 1919. 